\title{
SMEs' Access to Finance and Choice of Capital Structure in Turkey
}

\section{Tr BaşlıkEksik}

Seyid F. MAHMUD ${ }^{1}$

Tarık AKIN² https://orcid.org/0000-0003-2239-7830

https://orcid.org/0000-0001-7874-6943

\begin{abstract}
The paper analyzes behavior of SMEs in financing their working and fixed capital requirements. The cross-sectional sample employed in this paper is based on the comprehensive World Bank Enterprise Survey (WBES) database. Seemingly unrelated regression (SUR) method has been employed to estimate two separate models for working capital and fixed capital, respectively. The model(s) not only focuses on the behavior of SMEs but also analyzes the behavior of SMEs reporting 'access to finance' as a major impediment in their growth in the survey. The regression results indicate that SMEs in Turkey, despite reporting problems in accessing finance are more dependent on bank financing for working capital. The result is in contrast to the full sample findings where similar SMEs depend less on bank financing and more on internal funds. The result may suggest dominant role of Turkish banking sector compared to the sample at large and policies to support bank financing for the SMEs in Turkey. Furthermore, the results for fixed capital financing for the overall sample shows higher dependence on non-banking modes of finance, supporting the conclusion that equity market(s) may offer viable solution in addressing the fixed capital financing constraints.
\end{abstract}

Keywords: SME finance, access to finance, seemingly unrelated regression.

\section{ÖZET}

Bu çalışma, KOBi'lerin döner ve sabit sermaye yatırımlarına ilişkin davranışlarını ölçmeye çalışmaktadır. Çalışmada kullanılan kesit örneklem, Dünya Bankası Girişimcilik Anketine dayalıdır. Döner sermaye ve sabit sermaye yatırımlarına ilişkin iki ayrı model görünürde ilişkisiz regresyon (GiR) yöntemi kullanılarak tahmin edilmiştir. Bu modeller, sadece KOBI'lerin sermaye kullanımlarına ilişkin davranışlarını değil, finansa erişimde sorun yaşayan KOBI'lerin de davranışını ölçmeye çalışmaktadır. Regresyon sonuçları, Türkiye'de finansa erişimde sorun yaşayan KOBI'lerin bile döner sermaye finansmanında bankacılık kesimine bağlı olduğunu göstermektedir. Bu sonuçlar, tüm ülkeleri kapsayan ve finansa erişimde sorun yaşayan firmaların daha fazla öz sermayeye bağlı olduğunu gösteren dünya örneklemi ile farklılaşmaktadır. Türkiye'ye ilişkin bu sonuçlar, Türkiye'de bankacılık sisteminin baskın yapısı ve politika uygulamalarının KOBI'lerin bankacılık kanallarına erişimini sağlamaya yönelik olmasıyla açıklanabilir. Ayrıca, tüm ülkeleri kapsayan örneklem sabit sermaye yatırımlarının bankacılık dışı finansman kalemlerine daha fazla bağlı olduğunu göstermektedir. Bu durum, KOBI'lerin sabit sermaye finansmanı kısıtlarını aşmasında sermaye piyasalarının uygun bir çözüm olduğunu desteklemektedir.

Anahtar Kelimeler: КОВі finansmanı, finansa erişim, döner sermaye, sabit sermaye, görünürde ilişkisiz regresyon. 


\section{Introduction}

Turkey has maintained strong economic performance over the last decade. Small and medium-sized enterprises (SMEs) have played a significant role in this respect. ${ }^{1}$ However, SMEs in Turkey face impediments in getting access to finance which prevents them from reaching their medium and long-term potential. Fully cognizant of the role played by the SMEs in achieving sustainable and inclusive growth targets, government has introduced numerous policy measures to ease access to finance by SMEs'. These measures typically focus on easing access to bank loans through credit guarantees, interest subsidies, and direct lending. The main motivation for focusing on the credit markets is to overcome the credit-rationing problem, which arises from asymmetric information, adverse selection and moral hazard. Even securing financial sources by the SMEs does not automatically guarantee access to finance due to incompatibilities between types of available finance and their optimal capital structure. For example, supply of bank loans at high interest rates can be detrimental to the capital structure of the firm in the form of high capital expenditures, lower profits and distorted pricing behavior. Furthermore, high information asymmetries may make banks hesitant in extending credit to the SMEs, as it poses high risks without collaterals and lack of credible credit history of the borrowers. Apart from having access to finance problems, supply of external finance is also incompatible with the capital structure of the SMEs and it may lead to voluntarily exclusion of SMEs from the financial system.

Given these incompatibilities between supply of finance and the diverse capital structures of SMEs', this paper attempts to investigate whether there exists a relationship between SMEs' access to finance problems and their capital structure, such as financing of working and fixed capital. To test it empirically, we employ the World Bank Enterprise Survey (WBES), which is one of the most comprehensive firm-level data sets, covering over 135 world economies.

Section 2 presents descriptive measures about access to finance and sources of working and fixed capital for the SMEs in Turkey based on WBES. Section 3 discusses the role of firm characteristics in the determination of access to finance and the sources of working and fixed capital.
After the identification of relevant firm characteristics, Section 4 constructs an empirical model based on seeming unrelated regression (SUR) model, and presents analysis of our results. Finally, Section 5 makes policy recommendations based on the data analysis and regression results.

\section{Access to and Sources of Finance: Some Observations from the SMEs in Turkey}

The sources of finance for SMEs are expected to differ from large firms due to the differences in firm characteristics, access to information, and their perceptional differences. For example, Abdulsaleh and Worthington (2013) argue that there are at least three main differences between SMEs and large firms in their modes of financing. First, SMEs are more likely to be attached to commercial lenders, especially institutional lenders, for their short-term debt financing requirements. Second, the existence of information asymmetry is more severe in SMEs thus developing any long-term relationship is crucial to deal with the agency problem, in addition to issues pertaining to conventional mechanisms such as, signaling, monitoring and bonding (the provision of guarantee or collateral). Third, contrary to what the agency theory suggests, it is not clear whether debt can lower the agency costs resulting from information asymmetry, which arises due to different motives of owners and managers.

Traditional bank lending to SMEs poses more challenges as compared to large firms. This is mainly due to the greater difficulties that lenders face in assessing and monitoring SMEs. For example, SMEs often do not prepare audited financial statements with credible financial information and have no obligation to make public disclosures of their financial reports, causing asymmetric information problems. Moreover, the principle and agent problem is more acute in the SMEs compared to the large firms. Consequently, banks may charge higher interest rates and fees from the SMEs (Cusmano, 2013, 2015). Furthermore, venture capital and private equity industry is relatively new and entrepreneurs, especially in developing countries, have little familiarity with the equity model (Bouri et al., 2011). Apart from the aforementioned sources of financing differences, widespread use of supplier credit by SMEs compared to large firms is also been highligh-

${ }^{1}$ This paper adopts the definition of SMEs from the World Bank Enterprise Survey database, which defines an SME as an entity with 5 to 99 employees. In the analysis, we decompose the firms into three main groups based on their size. Small firms have employees between 5 and 20, medium-sized firms have employees between 21 and 99 and large firms are defined as firms with 100 or more employees. 
ted in the literature. Transaction and financing motives play an important role in this difference (Elliehausen \& Wolken, 1993). As underscored by Abdulsaleh and Worthington (2013):

The transaction motive suggests the better ability for both parties (the seller and the buyer) to predict their cash needs in the short-term. As such, cash management transaction costs can be economized. The financing motive is that SMEs resort to trade credit when alternative sources of finance are unavailable or more expensive.

Indeed, supplier or trade credit is a viable alternative mode of finance especially for young SMEs (Fatoki \& Odeyemi, 2010).

Given the overview of the main sources of finance for the SMEs, the rest of this section introduces the WBES dataset and discusses some observations from the WBES dataset regarding the sources of working capital and fixed capital needs of the SMEs, as well as, the relationship between the sources of finance and the SMEs' impediments in access to finance.

The Enterprise Surveys of the World Bank Group allow a detailed exploration of variation in the use of financial services across firms with different characteristics. These surveys have been conducted over the past 10 years in over 100 countries with standardized survey instruments and a uniform sampling methodology. The survey aims at capturing business perceptions of the most important obstacles to enterprise operation and growth, but also include detailed information on companies' management and financing arrangements. Sample sizes vary between 250 and 1,500 companies per country and data are collected using either simple random or randomly stratified sampling techniques. The sample includes formal enterprises of all sizes, different age groups, and different ownership types in manufacturing, construction, services, and transportation. Firms from different locations, such as the capital city, major cities, and small towns, are included (Beck \& Cull, 2014). In the original dataset, there are over 107,000 observations from 135 countries, 67 of which have at least two waves of surveys. In the current study, to interpret the results more clearly and to prevent having some confounding results, the database is re-formatted to generate a cross-section sample of firms. Only latest available surveys for each country have been included. After this process, the sample size, employed in this study, is reduced to around 80,000 . It should be noted from the outset that we utilize the full sample instead of just restricting the sample to Turkey. This strategy allows us to see whether there are statistically significant differences between Turkey and the rest of the world with respect to the explanatory variables and their relationships with sources of finance

Working capital refers to financing of short-term production activities and is essential to cover shortterm liquidity needs (World Bank, 2011). In the WBES questionnaire, the firms select one of internal funds/ retained earnings, bank loans, non-bank financial institutions, supplier credit and other means of financing as their primary sources of working capital. As per the design of the questionnaire, the sum of these sources of financing adds up to $100 \%$. Figure 1 shows the decomposition of the sources of working capital with respect to the SMEs and the large firms. Both SMEs and their large counterparts disproportionally depend on their retained earnings and internal funds for their working capital needs. However, dependence of the retained earnings and the internal funds is lower for the large firms as a reflection of their easier access to external finance. Bank lending is the second largest source of financing for the firms but its share is higher for the large forms due to their easier access to bank loans. The third important source for the financing of working capital is the supplier credit, especially for the export-oriented firms.

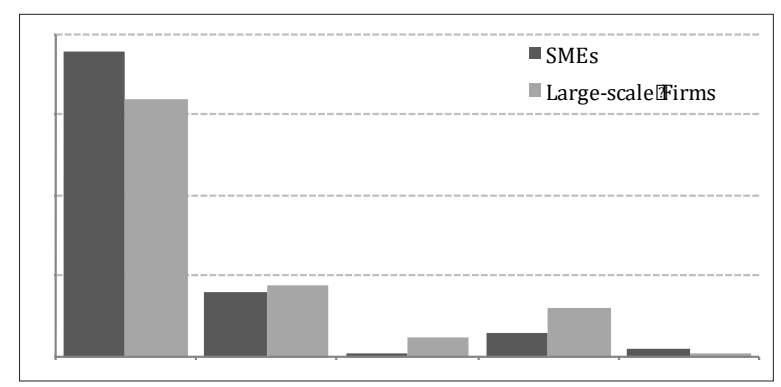

Source: World Bank Enterprise Surveys (September 2018 edition), Authors' calculations

Figure 1: Sources of Working Capital Financing

In the WBES, the firms are also specifically asked to rank their degree of having difficulty in access to finance. The question ( $k 30$ ) ranges from 1 to 5 and higher level indicates higher degree of self-reported obstacle in accessing to finance. Interclass (inter-cluster) correlations give a general idea of the association between the degree of having difficulty in access to finance and the sources of working capital. In such an investigation, positive correlation indicates more de- 
pendence on a mode of financing of working capital as access to finance becomes more severe for the firm.

Figure 2 illustrates the correlations of different sources of financing for the SMEs and the large firms. Negative association between having obstacle in access to finance and depending on more internal funds is a priori expected outcome because a firm with enough internal funds is possibly less dependent on external finance for a given level of financing need. However, the negative correlation coefficient is more pronounced for the SMEs, indicating that SMEs are much more sensitive to availability of finance for their current operations. Much higher positive correlation coefficients of bank lending and supplier credit for the SMEs compared to their larger counterparts also confirm that access to finance problems are more pertinently associated with access to bank credit and supplier credit. In other words, the main means of finance for the SMEs that give rise to their access to finance problems is limited access to credit.

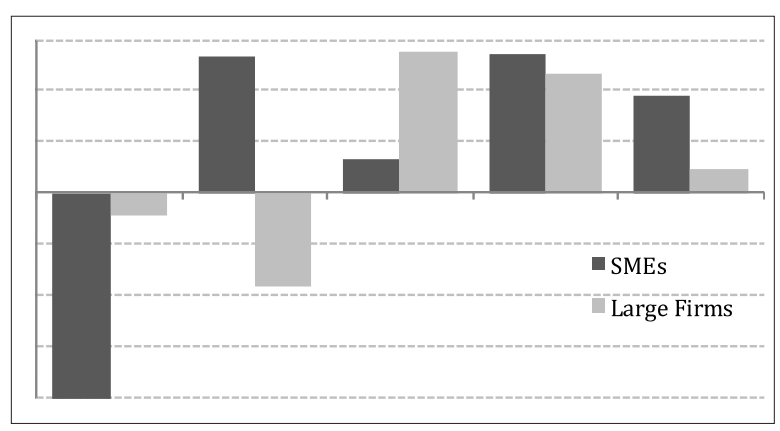

Source: World Bank Enterprise Surveys (September 2018 edition), Authors' calculations

Note: Survey-weighted observations are used through Stata's svy prefix.

Figure 2: Interclass Correlation between Having Obstacle in Access to Finance and Primary Sources of Working Capital

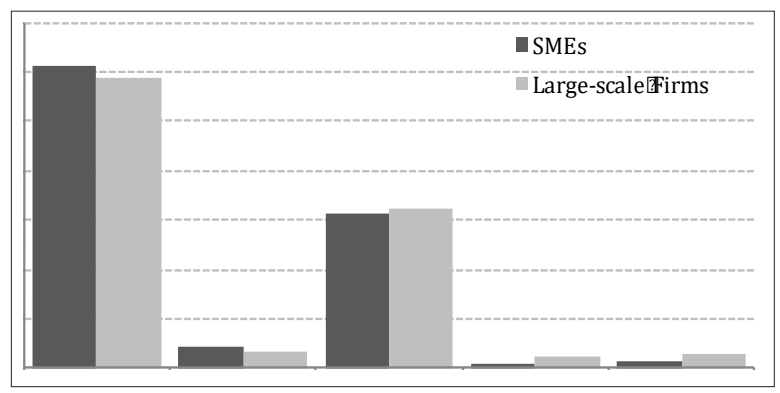

Source: World Bank Enterprise Surveys (September 2018 edition), Authors' calculations

Figure 3: Sources of Fixed Capital Financing
Fixed capital refers to larger investments related to capital accumulation, such as in machinery or equipment (World Bank, 2011). In the WBES questionnaire, the firms select one of internal funds/retained earnings, equity, bank loans, non-bank financial institutions, supplier credit and other means of financing as their primary source of working capital. As per the design of the questionnaire sum of these means of financing adds up to $100 \%$. Although sources of working capital are relatively more diversified, Figure 3 underlines that the bank credit is nearly the sole external source of finance for the firms for their fixed capital financing needs. Besides, the share of bank lending as the source of fixed capital financing needs, it is almost two-fold that of the working capital financing need for both types of firms.

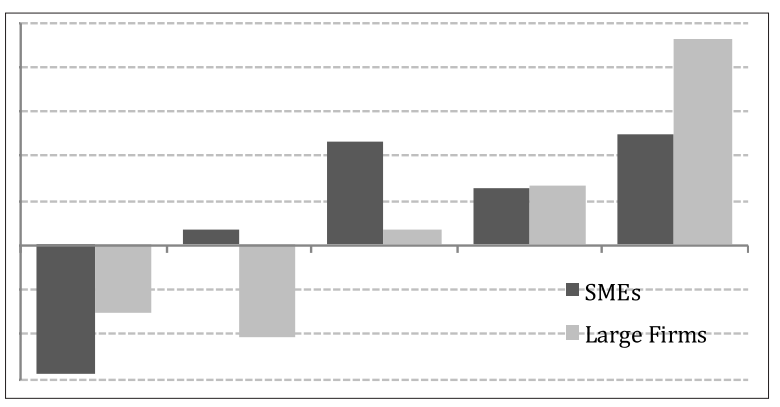

Source: World Bank Enterprise Surveys (September 2018 edition), Authors' calculations

Note: Survey-weighted observations are used through Stata's svy prefix.

Figure 4: Interclass Correlation between Having Obstacle in Access to Finance and Primary Sources of Fixed Capital

Figure 4 shows the interclass (inter-cluster) correlations between having obstacle in access to finance and primary sources of fixed capital. According to Figure 4, there is a negative association between equity issuance and impediments in access to finance for the large firms, which indicates that the large firms use equity issuance as a substitute for other means of financing. From the perspective of the SMEs, bank lending has the biggest positive correlation indicating that the bank lending seems to be the most important source of finance to surpass the access to finance problems. Supplier credit is another important source of financing for the SMEs that have obstacles in access to finance. 


\section{Role of Firm Characteristics on Access to Finance and Sources of Finance for SMEs}

In Section 2 important observations have been made about relationship between having obstacles in access to finance and resorting to a specific source of finance. In this section, empirical model has been developed to further explore the relationship between the two by incorporating various firm's characteristics WBES reveals more than sixty firm characteristics ranging from size, age, current legal status, and export-orientation to having a female manager, share of working capital financing, and perceptions of firms about legal system. It poses important challenge to identify some of the most relevant characteristics to construct a "parsimonious" structure of the model. Our selection process of the characteristics are primarily based on the review of relevant literature. Abdulsaleh \& Worthington (2013) emphasized size, age, ownership type, legal form, location, industry's sector, and asset structure as the most important firm characteristics. Batra \& Mahmood (2003) analyzed the WBES dataset to understand how a variety of firm characteristics affect the firms' experience and perceptions of the constraints. They conclude that the firms that are private, smaller, and younger, devoid of foreign direct investment (FDI) and focus on the domestic market generally tend to face more acute business constraints. Similarly, Kira (2013) found that industrial sector, incorporation, age, and ownership are the most pertinent firm's characteristics of SMEs in East Africa. Wignaraja \& Jinjarak (2015) also indicates that age, export participation, foreign ownership, managerial experience, financial audit, having ISO certificate and industry determines source of financing and type of collateral in East Asia. In addition to the aforementioned studies, there are many other studies at the country level, which underline age, ownership structure, management experience and industry as important firm characteristics in examining the financial structures of SMEs.

In line with the literature and relevance to SME financing, we include age, location, and ownership structure, industry in which an SME operates and share of exports in total sales as the most relevant firm characteristics pertinent to the financing structures of SMEs. Empirical analyses in the rest of this study also confirm that these five selected aspects of firm characteristics explain a great deal of the variation in preferences for different sources of financing.

\subsection{Firm Age}

Firm age ${ }^{2}$ is considered as one of the most important firm characteristics, which has important implications on the firms' access to finance and financing decisions as there is a direct link between age of a firm and its capital structure (Berger \& Udell, 1995; Bhaird \& Lucey, 2010) size, level of intangible activity, ownership structure and the provision of collateral are important determinants of the capital structure in SMEs. A generalisation of Zellners Journal of the American Statistical Association 57, 348368, 1962. Sources of financing differ over the life cycle of a firm. In the start-up stage, owner's personal savings are more important as a source of funds during the start-up stage than outside finance for SMEs but these funds are not usually to quench the financial needs of the firm fully (Storey, 1994).

In the early stages of the growth phase, bank loans, supplier/trade credits and leasing are the most important sources of financing while these sources are not sufficient to prevent liquidity problems. Towards the peak of the growth phase longer term financing becomes more important. On the other hand, insufficient availability of longer-term financing options, especially equity-based financing, give rise to "equity gap". Towards the maturity of the firm, equity and all other means of financing become available but loss of control and struggling against lower rate of return, which is reflected in the difficulty of attracting investors, are the main issues.

\subsection{Sectoral Decomposition}

While the WBES provides very detailed sectoral decomposition of the firms surveyed ${ }^{3}$, we aggregated the original decomposition into three consolidated sectors as "manufacturing", "services" and "others".

\subsection{Location of Firm}

Population size and its density are among the important determinants of firms' choice of financing and their access to finance. For instance, proximity to the financial centers or bank branches is an important self-declared reason for not applying for a

\footnotetext{
${ }^{2}$ In the World Bank Enterprise Survey, we don't have direct information on the age of the surveyed firms but the dataset has a variable on the year in which the firm started its operations; subtracting the survey year from this variable gives us the age of the firm.

${ }^{3}$ Stratified sectors have 48 and aggregated sectors have 15 subcomponents on the basis of ISIC-2 classification in the dataset.

${ }^{4}$ In the regressions, we transferred all these three variables into dummy variables.
} 
Ioan (Demirgüç-Kunt \& Klapper, 2012). There is also positive association between being in the proximity of banks and getting external finance, including but not limited to bank loans (Abdulsaleh \& Worthington, 2013). This gives rise to a dilemma for SMEs. On the one hand, SMEs prefer to work in urban areas to raise enough external finance for their operations; on the other hand, urban areas are possibly much more costly for them in terms of high rentals and other operating costs (Abor, 2008). Indeed, "the accumulated studies also touched upon differences in growth patterns between rural and urban SMEs even within the same industry and among firms of similar sizes, with urban SMEs recording higher growth rates than rural ones" (Shinozaki, 2012). The World Bank Enterprise Survey provides information on the size of the population in which an observation (firm) operates. Thus, we use this variable as a proxy for the location and rural/urban distinction in the analysis. ${ }^{5} \mathrm{~A}$ priori, a positive association between bigger city size and having less difficulty in access to finance is expected.

\subsection{Firm Ownership}

Ownership structure is assumed to be one of the important factors for private sector development, innovation and economic development. Indeed, in his blockbuster book Schumpeter underlines that entrepreneur is the prime propeller of economic development (Schumpeter \& Elliott, 1982). Importance of the ownership structure lies in the fact that the ownership structure as a reflection of corporate governance may substitute for institutional flaws in case institutional structure is not well-developed such as underdeveloped legal system and political rights (Balsmeier \& Czarnitzki, 2010). As a result, ownership structure is intimately pertinent to firm's financing choices and degree of impediments in access to finance. To give an example, incorporation may be considered as a positive sign with respect to formality and credibility by finance institutions, especially by banks (Cassar, 2004). The result then is a more favorable condition in getting external financing for the incorporations compared to sole proprietorships. Indeed, that limited private companies are more likely to be reliant on bank financing (Storey, 1994).

Access to finance is also associated with more efficient forms of organizations such as incorporation
(Beck, Demirgüç-Kunt, Laeven, \& Maksimovic, 2006). As underlined by Van Auken and Neeley (1996),

Owners launching firms organized as either a sole proprietorship or non-construction/manufacturing firms should be prepared to use more bootstrap financing than other firms. Owners of these types of firms should be prepared to develop a financial plan that incorporates the use of greater variety of financing alternatives than owners of firms organized other than a sole proprietorship non-construction / manufacturing firms. As such, a sole proprietorship of non-construction / manufacturing firms should recognize the potential for the associated greater number of constraints and difficulties in raising startup capital.

There are two variables in the WBES, each of which gives a different aspect of the ownership structure of the firms surveyed. One of the variables in the dataset informs about the current legal status or form of the firm. Other one gives information about who owns the firm and what share each owner has. In the WBES, legal status of the firm fits into one of public listed, limited liability, sole proprietorship, partnership, limited partnership and other types. For the sake of easier interpretation, we consolidate legal status of the firm under three rubrics, namely, sole proprietorship, partnership and corporation because each of them represents a different institutional and corporate variety.

\subsection{Export Orientation}

The final firm characteristic, included in our model, is whether a firm is export oriented or its sales are export dominant. In this paper, a firm is export-oriented if its export share in sales is higher than its domestic sales. While export-orientation is a good candidate for the purpose of measuring effect of exports on sources of financing and access to finance, this measure suffers from two deficiencies. First, export performance of a firm is not independent from its counterparts in the country so it may give biased results if we compare export orientation of two firms in different countries with very different levels of trade openness and export biasedness. Secondly, industries in which the SMEs partake in a given country may have very different shares of export averages. Hence, a second export performance indicator, export dominance is introduced. According to this indicator, if a firm has export share over the country average, it is considered as an

\footnotetext{
${ }^{5}$ In this respect, we classify the location or population variable as follows: Areas with population up to 50,000 is considered as a small city, with population between 50,000 and 1,000,000 are considered as medium sized city and with population over 1,000,000 or capital cities are considered as a large city. Although population decomposition is a bit arbitrary, the main driver of this classification is to have a proxy of location effect in firms' access to finance.
} 
export-dominated firm. Both of these indicators are employed in the analyses. In the WBES, firms are asked what share of their sales go to domestic markets, what shares of them are exported and what shares is exported indirectly. We aggregate direct and indirect exports as exports.

The literature emphasizes that export-oriented firms have easier access to finance (Arráiz, Meléndez, \& Stucchi, 2011). Moreover, export processing zones are more likely to receive bank loans compared to other locations (Ayyagari, Demirgüç-Kunt, \& Maksimovic, 2010). Empirical evidence supports that firms with better export performance have lower financing obstacles because of covered sunk cost of foreign market entry (Leitner \& Stehrer, 2013). On the other hand, positive relationship between being a firm with better export performance and having access to finance is empirically slightly significant in upper-income countries and exporting behavior doesn't give rise to more use of trade credit, leasing or informal financing (Brown, Chavis, \& Klapper, 2010).

\section{The Model}

Seemingly unrelated regression (SUR) model has been employed to determine the relationship between covariates of the sources of financing decisions with firm-level characteristics and SMEs related variables. The sources of financing decisions are based proportions of firms working capital and fixed asset purchases that have been financed by one of the given means of financing, as reported in the survey.

A system of equations is referred as seemingly unrelated regression (SUR) system if the error terms in the regression equations are contemporaneously correlated, even though these error terms superficially seem to be uncorrelated. Encompassing the correlations among the equations provides additional information which is over and above the information available when each of the equations are estimated separately. Powell's (2006). The seemingly unrelated regressions (SUR) model can be viewed as a special case of the generalized regression model given in equation:

$$
E(y)=X \beta, V(y)=\sigma^{2} \Omega
$$

The basic SUR model assumes that, for each individual observation $i$, there are $M$ dependent variables $y_{i 1}, y_{i 2}, \ldots \ldots, y_{i M}$, each with its own linear regression equation:

$$
y_{i j}=x_{i j}^{\prime} \beta_{j}+\varepsilon_{i j}, i=1, \ldots, N
$$

The standard conditions for the classical regression model are assumed to hold for the $j$ th firm:

$$
\begin{aligned}
& E\left(y_{j}\right)=X_{j} \beta_{j} \\
& V\left(y_{j}\right)=\sigma_{j j} \boldsymbol{I}_{N}
\end{aligned}
$$

with $X_{j}$ non-stochastic variables with rank $\left(X_{j}\right)=K_{j}$. With additional condition $y_{j}$ of multi-normality of, $y_{j}$ the usual inference theory is valid for the classical Least Square (LS) estimator of $\beta_{j}$ applied separately to each equation. However, the SUR model permits nonzero covariance between the error terms $\varepsilon_{i j}$ and $\varepsilon_{i k}$ for a given individual $i$ across equations $j$ and $k$, i.e.,

$$
\operatorname{Cov}\left(\varepsilon_{i j}, \varepsilon_{i k}\right)=\sigma_{i j}
$$

while assuming

$$
\operatorname{Cov}\left(\varepsilon_{i j}, \varepsilon_{i \prime k}\right)=0
$$

If $i \neq i^{\prime}$. This can be expressed more compactly in matrix form:

$$
\boldsymbol{C}\left(\varepsilon_{j}, \varepsilon_{k}\right)=\sigma_{j k} \boldsymbol{I}_{N}
$$

It is the non-zero covariance across equations $j$ and $k$ that allows for an improvement in efficiency of generalized least squares (GLS) relative to the classical LS estimator of each $\beta_{j}$. As the contemporaneous correlation structure justifies employing the SUR estimation method over the ordinary least squares (OLS), failure in meeting two requirements reduces the SUR to equation-by-equation OLS.

First is the obvious case of errors uncorrelated across equations, so $\sum$ is diagonal. The second case is less obvious but can often arise in practice. Even if $\Sigma$ is non-diagonal, if each equation contains exactly the same set of regressors, so $\mathrm{X}_{j}=\mathrm{X}_{j}$, for all $\mathrm{j}$ and $\mathrm{j}_{\text {, }}$ then it can be shown that the FGLS systems estimator reduces to equation-by-equation OLS" (Cameron \& Tridevi, 2010).

While the first requirement is easy to meet due to the fact that all of the dependent variables of the regression (means of financing) are directly dependent on each other as they must add up to $100 \%$, the second requirement needs adjustment in the covariates (explanatory variables). To secure meeting the second requirement we follow a very simple yet effective way of estimation. In the first step, we estimate the SUR 
system with the same covariates. In the second step, we drop the most insignificant covariate from each of the equations. This allows us to have slightly different covariates in each of the regressions in the system and to purge the covariates with no contribution to the estimation, if correlation between the purged covariate and the rest of the covariates are very low.

Given the SUR methodology explained above, the estimation strategy employed is to construct a system of equations for the financing choice of the firms by employing the SUR methodology to working capital and fixed capital, separately. The model specification is as follows:

$$
y_{i j}=x_{i j}^{\prime} \beta_{j}+\varepsilon_{i j}, i=1, \ldots, N
$$

In this regard, each dependent variable in each of the system of equations constitutes one of the modes of finance. There are five dependent variables (internal funds, bank loans, non-banking financial institutions, supplier credit and others) as sources of financing for working and fixed capital in this system of equations. Explanatory variables include firm's characteristics, SME dummy variables, proxies for firms' degree of impediments to access to finance, and several interactions of variables. The explanatory variables and their short description are given in Appendix 1.

\section{Results}

The primary focus of the study is to examine the behavior of those firms in the sample that have reported "accessing finance" as their major constraint in general and that of SMEs in particular. The empirical model also allows to examine firm's behavior with respect to their specific characteristics. Furthermore, we have included dummy variables to see whether the firms in Turkey differs from the rest of the world.

In Table 1 summary of significant results with the signs of the coefficients have been provided. The full regression results are given in Appendix 2 and Appendix 3 for the working capital and fixed capital cases respectively. It should also be noted here that standardized regression coefficients are given in Appendix 2 and Appendix 3 to determine the relative importance of each of the covariates in the regression framework. Thus, a coefficient gives an account of how many standard deviations a given source of financing changes as per one-unit standard deviation change in a covariate of interest.

Before presenting the regression results pertaining to SMEs and firms reporting access to finance as major impediment, we first discuss the overall results related to the specific characteristics of the firms. The regression outputs indicate that age of the firm has significant impact in choosing the mode of financing both for working capital and fixed capital financing needs. Older firms depend more on bank financing while reducing their dependence on internal mode of financing. The results for Turkish firms were not significantly different except they seem more dependent on 'supplier credit' for WC financing requirements. Another important finding from the regressions is that the manufacturing firms tend to use both internal funds and banking finance and depend less on supplier credits. The Turkish manufacturing firms, however, use internal funds for their working capital financing more compared to full sample results. Firms with greater share of their output in exports rely less on internal funds and depend more on the rest of the modes of finance. Turkish firms in this group are not statistically different from the rest of the world sample. It is in line with the priori expectation that the shareholding firms at large depend less on banking finance both for working capital and fixed capital financing needs. However, Turkish firms seem to depend less on internal funds and more on banking financing for their working capital financing needs. The results for fixed capital were not significant for Turkey. Finally, it should be noted that the SME's dependence on banking finance is less than most of the other modes of finance. SME's in Turkey use internal finance for working capital, whereas the result for the rest of the sample is not significant.

Detailed results related to SMEs and firms reporting access to finance as an important constraint in their growth are, for WC, are reported in Appendix 2. The regression results indicate that the SMEs in Turkey are forced to rely on their internal funds as their access to finance problems intensifies, although the positive association is smaller compared to the rest of the worId (0.06-0.04=0.02). This is an expected outcome in line with the results reported in the literature. However, use of bank loans for the working capital finance reveals few interesting results. The relationship is negative in the full sample (-0.08) but SMEs in Turkey are comparably biased towards using more bank loans as their access to finance problems intensify $(-0.08+0.07=0.01)$. This reflects the dominant role of the banking system in Turkey. Given the lack of other modes of finance for working capital, SMEs in Turkey resort to bank lending, irrespective of the interest rate(s) and other conditions of lending. Use of finance from the non-bank financial institutions also reveals interesting results for Turkey. 
Although there is no significant association in the full sample there is a negative association for the SMEs in Turkey indicating that the SMEs with less constraining access to finance obstacles resort to the non-bank financial institutions $(-0.03)$. There is also no significant association between access to finance and other modes of finance for working capital needs of the SMEs. The first regression output indicates that the SMEs in Turkey are more dependent on the banking system compared to their peers in the rest of the world even if they have limited access to finance for their working capital needs. Furthermore, the negative association between access to finance variable and use of finance from the non-bank financial institutions implies that there is an opportunity for the firms to resort to the non-bank financial institutions.

Appendix 3 presents the results of relationship between access to finance and components of the fixed capital by the firms based on the SUR model. The regression output in Appendix 3 indicates that there is no significant association between the use of the internal funds and access to finance problems.
There is also a negative association between having more obstacles in access to finance and use of equity as a means of fixed capital finance $(-0.04)$. There is no difference with respect to this association between the SMEs in turkey and the rest of the world. This is an expected result from the literature since equity-based finance requires managerial, institutional and financial capability of the firms that are negatively related to the access to finance problems. Interestingly, there is no significant association regarding the relationship between having problems in access to finance and resorting to the bank loans. There is also no significant association regarding the relationship between having problems in access to finance and resorting to the finance from the non-bank financial institutions, as well as, supplier credit. On the other hand, the association is positive and quite high (0.05) between having problems in access to finance and resorting to the finance from other sources of finance. The second regression output indicates that there is big room for the SMEs to resort to the equity market for overcoming their access to finance problems.

Table 1: Sign of the Statistically Significant Explanatory Variables in the Regression Framework

\begin{tabular}{|c|c|c|c|c|c|c|c|c|c|c|c|c|}
\hline & \multicolumn{2}{|c|}{ Internal Funds } & \multicolumn{2}{|c|}{$\begin{array}{l}\text { Banking } \\
\text { Finance }\end{array}$} & \multicolumn{2}{|c|}{ Equity } & \multicolumn{2}{|c|}{$\begin{array}{l}\text { Non-Bank Fin. } \\
\text { Institutions }\end{array}$} & \multicolumn{2}{|c|}{ Supplier Credit } & \multicolumn{2}{|c|}{ Other } \\
\hline & WC & $\mathrm{FC}$ & WC & $\mathrm{FC}$ & WC & $\mathrm{FC}$ & WC & $\mathrm{FC}$ & WC & $\mathrm{FC}$ & WC & FC \\
\hline firmage & - & - & + & + & $\mathrm{N} / \mathrm{A}$ & & & + & & & - & - \\
\hline firmage_tr & & & & & $\mathrm{N} / \mathrm{A}$ & & & & + & & & \\
\hline dummanuf & + & + & + & + & $\mathrm{N} / \mathrm{A}$ & + & & & - & & - & \\
\hline dummanuf_tr & + & & & & $\mathrm{N} / \mathrm{A}$ & & & & & & & \\
\hline dumserv & - & + & + & + & $\mathrm{N} / \mathrm{A}$ & & & & & & & \\
\hline dumserv_tr & + & & + & & $\mathrm{N} / \mathrm{A}$ & & & & + & & & \\
\hline population & & + & - & - & $\mathrm{N} / \mathrm{A}$ & & + & - & - & & + & \\
\hline population_tr & & & & + & $\mathrm{N} / \mathrm{A}$ & - & - & & & & & \\
\hline soleprop & + & + & - & - & $\mathrm{N} / \mathrm{A}$ & & + & & & & + & + \\
\hline soleprop_tr & - & + & + & & $\mathrm{N} / \mathrm{A}$ & & & & & & & \\
\hline sharehold & + & + & - & - & $\mathrm{N} / \mathrm{A}$ & - & + & + & + & + & - & \\
\hline sharehold_tr & - & & + & & $\mathrm{N} / \mathrm{A}$ & & & & & & & \\
\hline exportshare & - & - & + & + & $\mathrm{N} / \mathrm{A}$ & + & + & + & + & + & + & + \\
\hline exportshare_tr & & & & & $\mathrm{N} / \mathrm{A}$ & & + & & & & & + \\
\hline smedum & & & - & - & $\mathrm{N} / \mathrm{A}$ & + & & & + & + & + & \\
\hline smedum_tr & + & & - & & $\mathrm{N} / \mathrm{A}$ & & + & & & & & \\
\hline accessfin & - & - & + & + & $\mathrm{N} / \mathrm{A}$ & + & + & & + & + & + & \\
\hline accessfin_tr & & & - & & $\mathrm{N} / \mathrm{A}$ & - & & & & + & & \\
\hline sme_accessfin & + & & - & & $\mathrm{N} / \mathrm{A}$ & - & & & - & & + & + \\
\hline sme_accessfin_tr & - & & + & & $\mathrm{N} / \mathrm{A}$ & & - & & & & & \\
\hline
\end{tabular}




\section{Coonclusion}

The primary aim of this paper is to analyze the behavior of firms that are more constrained in accessing finance with particular emphasis on SMEs The World Bank Enterprise Survey (WBES) data, covering over 135 world economies, have been employed. Using Seemingly Related Regression (SUR) method, two separate empirical models have been estimated for financing of working capital (WC) and fixed capital. The explanatory variables describing various characteristics of the firm have also been included in the model as control variables.

Several interesting results have been obtained for the general characteristics of the firms and their preferences for the modes of financing working and fixed capital requirements. First, older firms seem to depend less on internal financing and more on bank financing both for the WC and FC. However, firms in the manufacturing and services sectors rely both on internal fund and bank financing. The Turkish firms were not found to behave differently than the full sample results. Second, the firms with greater share in exports rely on all modes of finance, however, they depend less on their internal funds. Again Turkish firms in this group were not found to be different.

The results pertaining to SMEs and SMEs reporting access to finance as one of the major constraints presents several interesting results. First, SMEs having problems with access to finance depend less on bank financing and depend more on their internal funds for WC, however, Turkish SMEs in the same group depend more on bank financing and less on their internal funds. This may suggest a more dominant role of banks in Turkey as compared to the rest of countries covered in the sample. The results for financing of FC, however, were not significant. Second, the association between having problems in access to finance is significantly positive and other sources of financing. The results do support the conclusion that there is potential for equity markets to address the financing issues. 


\section{REFERENCES}

Abdulsaleh, A. M., \& Worthington, A. C. (2013). Small and Medium-Sized Enterprises Financing: A Review of Literature. International Journal of Business and Management, 8(14), 36-54. https://doi.org/10.5539/ ijbm.v8n14p36

Abor, J. (2008). Determinants of the Capital Structure of Ghanaian Firms (No. 176). AERC Research Paper. Nairobi.

Arráiz, I., Meléndez, M., \& Stucchi, R. (2011). The Effect of Partial Credit Guarantees on Firm Performance: the Case of the Colombian National Guarantee Fund (Working Paper Series 0212).

Ayyagari, M., Demirgüç-Kunt, A., \& Maksimovic, V. (2010). Formal versus Informal Finance: Evidence from China. Review of Financial Studies, 23(8), 3048-3097. https://doi.org/10.1093/rfs/hhq030

Balsmeier, B., \& Czarnitzki, D. (2010). Ownership Concentration Institutional Development and Firm Performance in Central and Eastern Europe. ZEW Discussion Paper (Vol. 10-096). https://doi.org/10.1002/ mde. 2751

Batra, G., \& Mahmood, S. (2003). Direct Support to Private Firms: Evidence on Effectiveness (No. 3170). World Bank Policy Research Working Paper.

Beck, T., Demirgüç-Kunt, A., Laeven, L., \& Maksimovic, V. (2006). The determinants of financing obstacles. Journal of International Money and Finance, 25(6), 932-952. https://doi.org/10.1016/j.jimonfin.2006.07.005

Berger, A. N., \& Udell, G. F. (1995). Relationship Lending and Lines of Credit in Small Firm Finance. The Journal of Business, 68(3), 351. https://doi. org/10.1086/296668

Bhaird, C. mac an, \& Lucey, B. (2010). Determinants of Capital Structure in Irish SMEs. Small Business Economics, 35(3), 357-375.

Bouri, A., Breij, M., Diop, M., Kempner, R., Klinger, B., \& Stevenson, K. (2011). Report on Support to SMEs in Developing Countries Through Financial Intermediaries. Dalberg Global Development Advisors, (November), 48. Retrieved from http://eudevdays. eu/sites/default/files/dalberg_sme-briefing-paper. pdf

Brown, G. W., Chavis, L. W., \& Klapper, L. F. (2010). Institutions, External Financing, and Growth around the World: A New Lease on Life? AFA 2008 New Orleans Meetings Paper. Durham, NC: American
Finance Association. https://doi.org/10.1017/ CBO9781107415324.004

Cameron, A. C., \& Tridevi, P. K. (2010). Microeconometrics Using Stata (Revised). Stata Press.

Cassar, G. (2004). The Financing of Business Start-ups. Journal of Business Venturing, 19(2), 261-283.

Cusmano, L. (2013). SME and Entrepreneurship Financing: The Role of Credit Guarantee Schemes and Mutual Guarantee Societies in supporting finance for small and medium-sized enterprises, 33(2012), 1-65. Retrieved from http://www.oecd. org/officialdocuments/publicdisplaydocumentpd$\mathrm{f} /$ ?cote $=$ CFE/SME(2012) $1 /$ FINAL\&docLanguage $=$ En

Cusmano, L. (2015). New approaches to SME and Entrepreneurial Financing: Broadening the Range of Instruments. Paris: Organisation for Economic Co-operation and Development.

Demirgüç-Kunt, A., \& Klapper, L. (2012). Measuring Financial Inclusion: The Global Findex Database (Policy Research Working Paper No. 6025). Washington, D.C.

Elliehausen, G. E., \& Wolken, J. D. (1993). The Demand for Trade Credit : An Investigation of Motives for Trade Credit Use by Small Businesses (Staff Studies No. 165).

Fatoki, O., \& Odeyemi, A. (2010). The Determinants of Access to Trade Credit by New SMEs in South Africa. African Journal of Business Management, 4(13), 2763-2770.

Kira, A. R. (2013). Determinants of Financing Constraints in East African Countries'SMEs. International Journal of Business and Management, 8(8), 49-68. https:// doi.org/10.5539/ijbm.v8n8p49

Leitner, S. M., \& Stehrer, R. (2013). Access to Finance and Funding Composition During the Crisis: A Firm-level analysis of Latin American Countries. Latin American Journal of Economics, 50(1), 1-47. https://doi.org/10.7764/LAJE.50.1.1

Powell, J. L. (2006). Zellner's Seemingly Unrelated Regressions Model. Department of Economics, University of California-Berkeley.

Schumpeter, J. A., \& Elliott, J. E. (1982). The Theory of Economic Development: An Inquiry into Profits, Capital, Credit, Interest, and the Business Cycle. Transaction Publishers.

Shinozaki, S. (2012). A New Regime of SME Finance in Emerging Asia: Empowering Growth-Oriented SMEs to Build Resilient National Economies (ADB Working Paper Series on Regional Economic Integration No. 104). 
Storey, D. J. (1994). Understanding the Small Business Sector. Cengage Learning EMEA.

Van Auken, H. E., \& Neeley, L. (1996). Evidence of Bootstrap Financing among Small Start-Up Firms. Journal of Entrepreneurial and Small Business Finance, 5(3), 235-249.

Wignaraja, G., \& Jinjarak, Y. (2015). Why Do SMEs Not Borrow More from Banks? Evidence from the People's Republic of China and Southeast Asia. ADBI Working
Paper Series. Tokyo. Retrieved from http://www. adbi.org/working- paper/2015/01/09/6523.why. do.sme.not.borrow.from.banks/

World Bank. (2011). World Bank's Enterprise Survey Understanding the Questionnaire. The World Bank. Washington, D.C. Retrieved from http://www. enterprisesurveys.org/ /media/GIAWB/EnterpriseSurveys/Documents/Methodology/Questionnaire-Manual.pdf 


\section{Appendix 1: Explanatory Variables in the Regression Framework}

\begin{tabular}{|c|c|}
\hline Variables & Description \\
\hline firmage & Age of firm in years \\
\hline firmage_tr & Age of firm in years*Turkey dummy \\
\hline dummanuf & Dummy variable, $=1$ if the main activity of firm is manufacturing \\
\hline dummanuf_tr & Dummy variable, $=1$ if the main activity of firm is manufacturing*Turkey dummy \\
\hline Dumserv & Dummy variable, $=1$ if the main activity of firm is services \\
\hline dumserv_tr & Dummy variable, $=1$ if the main activity of firm is services*Turkey dummy \\
\hline population & Location of the firm, see footnote 7 for further information \\
\hline population_tr & Location of the firm*Turkey dummy \\
\hline soleprop & Dummy variable, $=1$ if legal status of firm is sole proprietorship \\
\hline soleprop_tr & Dummy variable, $=1$ if legal status of firm is sole proprietorship*Turkey dummy \\
\hline sharehold & Dummy variable, $=1$ if legal status of firm is corporation \\
\hline sharehold_tr & Dummy variable, $=1$ if legal status of firm is corporation*Turkey dummy \\
\hline exportshare & Share of export in total sales (as \% of total) \\
\hline exportshare_tr & Share of export in total sales (as \% of total)*Turkey dummy \\
\hline Smedum & SME dummy, $=1$ if the firm is an SME \\
\hline smedum_tr & SME dummy, $=1$ if the firm is an SME*Turkey dummy \\
\hline accessfin & $\begin{array}{l}\text { Degree of obstacles in access to finance ( } 1 \text { to } 5 \text { : higher level means more severe is the access to } \\
\text { finance) }\end{array}$ \\
\hline accessfin_tr & $\begin{array}{l}\text { Degree of obstacles in access to finance ( } 1 \text { to } 5 \text { : higher level means more severe is the access to } \\
\text { finance) *Turkey dummy }\end{array}$ \\
\hline sme_accessfin & Interaction variable of SME dummy*access to finance variable \\
\hline sme_accessfin_tr & Interaction variable of SME dummy*access to finance variable* Turkey dummy \\
\hline
\end{tabular}


Appendix 2: Seemingly Unrelated Regression (Standardized Coeffs): Working Capital

\begin{tabular}{|c|c|c|c|c|c|c|}
\hline & & Internal Funds & Bank Financing & $\begin{array}{l}\text { Non-Bank Financial } \\
\text { Institutions }\end{array}$ & $\begin{array}{l}\text { Supplier } \\
\text { Credit }\end{array}$ & Other \\
\hline \multirow{14}{*}{ 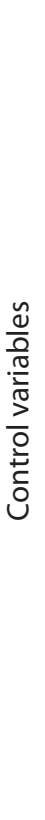 } & firmage & $-0.02^{* * *}$ & $0.02^{* * *}$ & -0.00 & $0.02^{* * *}$ & $-0.01^{* * *}$ \\
\hline & firmage_tr & 0.01 & 0.00 & -0.00 & $-0.02^{* *}$ & 0.00 \\
\hline & dummanuf & $1.09 * * *$ & $0.51^{* * *}$ & -0.00 & 0.00 & $-0.03^{*}$ \\
\hline & dummanuf_tr & -0.01 & dropped & 0.00 & 0.02 & 0.01 \\
\hline & dumserv & $1.13^{* * *}$ & $0.43^{* * *}$ & dropped & $0.01 * *$ & -0.01 \\
\hline & dumserv_tr & $-0.02^{* *}$ & $0.01^{* * *}$ & dropped & 0.01 & 0.01 \\
\hline & population & $0.08^{* * *}$ & $-0.09 * * *$ & $0.01^{* *}$ & $-0.04^{* * *}$ & $0.03^{* * *}$ \\
\hline & population_tr & 0.01 & -0.00 & $-0.04^{* * *}$ & 0.01 & -0.01 \\
\hline & soleprop & $0.10^{* * *}$ & $-0.15^{* * *}$ & $0.02^{* * *}$ & dropped & $0.02^{* * * *}$ \\
\hline & soleprop_tr & $-0.02^{* *}$ & $0.02^{* * *}$ & 0.01 & dropped & -0.01 \\
\hline & sharehold & $0.05^{* * * *}$ & $-0.10^{* * *}$ & $0.02^{* * *}$ & $0.05^{* * *}$ & $-0.01^{* *}$ \\
\hline & sharehold_tr & $-0.03^{* *}$ & $0.04^{* *}$ & 0.01 & -0.01 & dropped \\
\hline & exportshare & $-0.07^{* * *}$ & $0.04^{* * *}$ & $0.04^{* * *}$ & $0.02^{* * *}$ & $0.04^{* * *}$ \\
\hline & exportshare_tr & dropped & -0.00 & $0.01 *$ & 0.00 & 0.00 \\
\hline \multirow{8}{*}{ 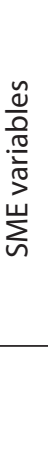 } & smedum & 0.01 & $-0.04^{* * *}$ & 0.01 & $0.02^{* * * *}$ & $0.03^{* * *}$ \\
\hline & smedum_tr & $0.04^{* *}$ & $-0.03^{* *}$ & $0.03^{*}$ & -0.03 & -0.01 \\
\hline & accessfin & $-0.17^{* * *}$ & $0.12^{* * *}$ & $0.04^{* * *}$ & $0.09 * * *$ & $0.04^{* * *}$ \\
\hline & accessfin_tr & 0.02 & $-0.05^{* * *}$ & 0.03 & 0.02 & -0.00 \\
\hline & sme_accessfin & $0.06^{* * * *}$ & $-0.08^{* * *}$ & 0.00 & $-0.03^{*}$ & $0.03^{* *}$ \\
\hline & sme_accessfin_tr & $-0.04^{* * *}$ & $0.07^{* * * *}$ & $-0.03^{*}$ & -0.00 & -0.00 \\
\hline & $N$ & 54,406 & 54,406 & 54,406 & 54,406 & 54,406 \\
\hline & $R$-square & 0.0400 & 0.0504 & 0.00426 & 0.0109 & 0.0113 \\
\hline
\end{tabular}

${ }^{*} p<0.10,{ }^{* *} p<0.05,{ }^{* * *} p<0.010$

Source: World Bank Enterprise Surveys Database

Survey-weighted observations are used through Stata's svy prefix. 


\section{Appendix 3: Seemingly Unrelated Regression (Standardized Coeffs): Fixed Capital}

\begin{tabular}{|c|c|c|c|c|c|c|c|}
\hline & & Internal Funds & Equity & $\begin{array}{c}\text { Bank } \\
\text { Financing }\end{array}$ & $\begin{array}{l}\text { Non-Bank Financial } \\
\text { Institutions }\end{array}$ & $\begin{array}{l}\text { Supplier } \\
\text { Credit }\end{array}$ & Other \\
\hline \multirow{14}{*}{ 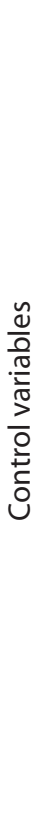 } & firmage & $-0.03^{* * *}$ & & $0.03^{* * * *}$ & $0.04^{* * * *}$ & -0.00 & $-0.02 * * *$ \\
\hline & firmage_tr & -0.00 & & 0.00 & -0.00 & -0.01 & 0.00 \\
\hline & dummanuf & $0.88^{* * *}$ & $0.02^{* *}$ & $0.49 * * *$ & & 0.00 & 0.00 \\
\hline & dummanuf_tr & 0.01 & 0.03 & -0.02 & & -0.01 & -0.03 \\
\hline & dumserv & $0.90^{* * *}$ & 0.00 & $0.46^{* * *}$ & -0.00 & 0.03 & 0.01 \\
\hline & dumserv_tr & & 0.02 & -0.01 & 0.01 & -0.01 & -0.01 \\
\hline & population & $0.08^{* * *}$ & -0.01 & $-0.10^{* * *}$ & $-0.02^{* *}$ & & $0.01 *$ \\
\hline & population_tr & -0.03 & $-0.05^{*}$ & $0.05^{* *}$ & 0.01 & & 0.00 \\
\hline & soleprop & $0.10^{* * * *}$ & -0.01 & $-0.14^{* * *}$ & 0.01 & 0.00 & $0.04^{* * * *}$ \\
\hline & soleprop_tr & $-0.03^{* *}$ & 0.02 & 0.03 & -0.00 & 0.01 & -0.01 \\
\hline & sharehold & $0.05^{* * *}$ & $-0.02^{* *}$ & $-0.09 * * *$ & $0.05^{* * *}$ & $0.04^{* * *}$ & \\
\hline & sharehold_tr & -0.04 & 0.05 & 0.03 & -0.03 & -0.01 & \\
\hline & exportshare & $-0.05^{* * *}$ & $0.03^{* * *}$ & $0.02^{* *}$ & $0.01^{*}$ & $0.05^{* * *}$ & $0.02^{* * *}$ \\
\hline & exportshare_tr & -0.00 & -0.00 & & 0.01 & -0.02 & $0.02^{* * *}$ \\
\hline \multirow{8}{*}{ 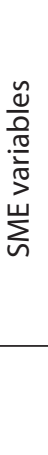 } & smedum & 0.00 & $0.03^{* *}$ & $-0.06^{* * *}$ & 0.02 & $0.04^{* *}$ & 0.02 \\
\hline & smedum_tr & 0.02 & -0.02 & -0.02 & -0.02 & 0.01 & 0.02 \\
\hline & accessfin & $-0.11^{* * *}$ & $0.07^{* * * *}$ & $0.05^{* * *}$ & 0.02 & $0.06^{* * *}$ & 0.02 \\
\hline & accessfin_tr & 0.00 & $-0.04^{*}$ & -0.01 & 0.02 & $0.05^{* *}$ & -0.00 \\
\hline & sme_accessfin & 0.01 & $-0.04^{* *}$ & -0.00 & 0.01 & -0.01 & $0.05^{* *}$ \\
\hline & sme_accessfin_tr & -0.01 & 0.03 & 0.03 & -0.01 & -0.04 & -0.02 \\
\hline & $N$ & 18,942 & 18,942 & 18,942 & 18,942 & 18,942 & 18,942 \\
\hline & $R$-square & 0.0311 & 0.00339 & 0.0367 & 0.00604 & 0.00766 & 0.0105 \\
\hline
\end{tabular}

${ }^{*} p<0.10,{ }^{* *} p<0.05,{ }^{* * *} p<0.010$

Source: World Bank Enterprise Surveys Database

Survey-weighted observations are used through Stata's svy prefix. 